\title{
LARVICIDAL EFFICACY OF Verbascum spp. METHANOL EXTRACTS AGAINST Plodia interpunctella (HÜBNER, 1813) (LEPIDOPTERA: PYRALIDAE)
}

\author{
Dragana Z. Predojević ${ }^{1 *}$, Filip N. Vukajlović1 ${ }^{\text {, Vladimir B. Mihailović }}{ }^{2}$, \\ Snežana T. Tanasković̉ ${ }^{3}$, Snežana B. Pešić ${ }^{1}$
}

\author{
${ }^{1}$ University of Kragujevac, Faculty of Science, Institute of Biology and Ecology, \\ Radoja Domanovića 12, 34000 Kragujevac, Serbia \\ ${ }^{2}$ University of Kragujevac, Faculty of Science, Institute of Chemistry, \\ Radoja Domanovića 12, 34000 Kragujevac, Serbia \\ ${ }^{3}$ University of Kragujevac, Faculty of Agronomy, Cara Dušana 34, 32000 Čačak, Serbia \\ *Corresponding author; E-mail: dragana.predojevic@pmf.kg.ac.rs
}

(Received April 30th, 2020; Accepted June 10th, 2020)

\begin{abstract}
Verbascum species (fam. Scrophulariaceae) contain a high concentration of rotenone and verbascoside and traditionally have long been used as insecticides. This study is aimed to investigate the larvicidal efficacy of Verbascum thapsus L. and $V$. phlomoides L. methanolic extracts in the suppression of the Plodia interpunctella (Hübner, 1813), under laboratory conditions. The experiment was set up in two separate blocks (for two different extracts), each as $3^{\times} 3^{\times} 3$ factorial trial: three concentrations of extracts $(1,2$ and $5 \%)$ were tested against the three larval age groups $(14,14-28$ and 28 days old $)$ and each treatment was repeated three times. Mortality was recorded after 24, 48, 72, and $96 \mathrm{~h}$. Both tested extracts were the most effective $96 \mathrm{~h}$ after the exposure in 5\% concentration applied on the youngest larvae. Extract of $V$. thapsus caused the mortality of $64.00 \%$, while in treatment with $V$. phlomoides extract mortality was $48.00 \%$. Tested Verbascum extracts have shown moderate potential for application as botanical larvicides.
\end{abstract}

Keywords: botanical insecticide, Indian meal moth, rotenone, plant extracts.

\section{INTRODUCTION}

Indian meal moth, Plodia interpunctella (Hübner, 1813) (Lepidoptera: Pyralidae) is a major cosmopolitan insect pest of a variety of stored food commodities (NAVARRO and NAVARro, 2018; PredoJeViĆ et al., 2017; VuKaJlović et al., 2017, 2019), particularly cereals, such as maize and wheat (JACOBS and CALVIN, 1990; PREDOJEVIĆ et al., 2017). Larvae of $P$. interpunctella are polyphagous and cause huge losses in the quality and quantity of infested cereals (PHILLIPS et al., 2000). Damages are reflected through the presence of larval feces, silken web, exuviae, and unpleasant odor of contaminated commodities.

To ensure the future of global food security, the major focus should be directed on reducing post-harvest losses (NAYAK and DAGLISH, 2018). Chemical control nowadays repre- 
sents the main tool for controlling stored product pests. Many scientific studies are focused on finding alternative, safer, and more effective methods to protect stored cereals from $P$. interpunctella infestation (KHOSHNOUD and KHAYAMY, 2008; CAMPOS et al., 2018; VUKAJLOVIĆ et al., 2019). The application of chemical pesticides has led to many negative effects, such as the evolution of pest resistance and environmental pollution (SABER et al., 2004).

Plants synthesize many natural substances, primary and secondary metabolites as a chemical defense against herbivores, especially insects (HARTMANN, 1999). Some of those, particularly secondary metabolites, could be used as natural insecticides in fields and storages (JBILOU et al., 2006). The application of these compounds is a much safer and environmentally friendlier method for storage pest control, unlike the application of synthetic insecticides. Pesticidal plants are usually used in two ways: the raw or dried plant tissues or extracts are used directly; or the active compounds are isolated, identified, and synthesized and produced by the chemical industry (YANG and TANG, 1988).

Many studies are being conducted to find a new and efficient source of botanical insecticides (SABER et al., 2004; HARTMANN, 1999; JBILOU et al., 2006; VUKAJLOVIĆ et al., 2019; GRDIŠA and GRŠIĆ, 2013). Plant species with confirmed insecticidal effects are being traditionally used in crop protection. Species of the genus Verbascum (Scrophulariaceae) have been used for a long time as very effective traditional sources of insecticides (KHOSHNOUD and KhayAmy, 2008; Gross and Werner, 1978; Riaz et al., 2013). Phytochemical studies of Verbascum plants showed the presence of different classes of secondary metabolites, mainly phenolic compounds and terpenoids. Phenylethanoid glycosides, flavonoids, iridoids, and saponins are reported as the major constituents of these species (GEORGIEV et al., 2011). Their insecticidal properties are scientifically confirmed against different insects, such as stored product pests Sitophilus oryzae (Linnaeus, 1763) (Coleoptera: Curculionidae), Tribolium castaneum (Herbst, 1797) (Coleoptera: Tenebrionidae) (KHOSHNOUD and KHAYAMY, 2008) and larvae of mosquito Aedes aegypti (Linnaeus, 1762) (Diptera: Culicidae) (SUPAVARN et al., 1974). Later has been discovered that Verbascum insecticidal efficacy is due to the high content of isoflavonoid rotenone in their leaves (FOSTER and DUKE, 2003). According to a research conducted by the US EPA in 1990, rotenone was found to be commonly used as a pesticide for insect control in home gardens, classified as a botanical insecticide (BRIGGS, 1992; GUPTA, 2019). It is a contact and, as well systemic insecticide (GUPTA, 2019). Rotenone can block the respiration of insects by inhibition of electron transport of the complex I in the mitochondrial respiratory chain (FANG and CASIDA, 1998; CABONI et al., 2004). It has been used as an insecticide for over a century (ISMAN, 2006). Although rotenone has been proven to be neurotoxicant, and in metabolic pathways converts in toxic metabolites in insects and fishes, while in nontoxic in mammals, it can be a component of an insecticide only if it is used in safe doses, nontoxic to vertebrates (GUPTA, 2019). A wide spectrum of industrial insecticides containing rotenone such as Bonide Rotenone 5 (DAYAN et al., 2009) or formulated in Barbasco, Chem-Fish, Cuberol, Rotacide, Tubatoxin, Green Cross Warble Powder, etc. (GUPTA, 2007).

Guided by the fact that bioactive components of Verbascum plants have a certain insecticidal effect, the aim of this study was to determine the larvicidal efficacy of $V$. thapsus and $V$. phlomoides methanol extracts, isolated from plants collected in Serbia, against different age groups of $P$. interpunctella larvae, on wheat, in laboratory conditions. Chemical profile and antioxidant activity of the extracts used in our research were investigated and published by MinaiLović et al. (2016). As far as we know, V. phlomoides insecticidal potential as well as the insecticidal efficacy of Verbascum spp. extracts against any lepidopteran storage pest is investigated for the first time. 


\section{MATERIALS AND METHODS}

\section{Insect population}

Plodia interpunctella larvae used in this research originated from the laboratory population, reared for $\approx 50$ generations in the Laboratory of General and Applied Entomology, at the Faculty of Science, University of Kragujevac, Republic of Serbia. Larvae were reared in transparent, plastic containers $(1.2 \mathrm{~L}$ in volume) for mass rearing, on standard laboratory diet for $P$. interpunctella (SILHACEK and MILLER, 1972), in the chamber set at 28 $\pm 1^{\circ} \mathrm{C}$, r. h. $60 \pm 10 \%$ and 14:10 (L:D) photoperiod.

\section{Wheat}

Grains of a winter wheat cultivar Takovčanka were used as a nutritive substrate. The grains were not treated with insecticides after the harvest or before setting up the experiment but were exposed to deep freezing $\left(-80^{\circ} \mathrm{C}\right)$ for two days, in order to eliminate the possible presence of storage insect pests and parasites.

\section{The plant material and preparation of the extracts}

Verbascum plants were collected during the flowering season in August 2010. The voucher specimens were deposited at the Department of Biology and Ecology, Faculty of Science, University of Kragujevac. Their voucher specimens and localities are V. phlomoides: Suva Planina, the mountain in southeastern Serbia (291 km from Belgrade), voucher no. 114/014 and for $V$. thapsus: Trgovište, south Serbia (295 km from Belgrade), voucher no. $115 / 014$.

The above-ground parts of $V$. phlomoides and $V$. thapsus were air-dried, fine powdered and separately extracted with methanol by maceration (MiHAILOVIĆ et al., 2016). The extracts used for larvicidal studies were dissolved in deionized water and applied in experiments at concentrations of 1,2 , and $5 \%$.

\section{Experimental design and procedure}

The experiment was set up in two separate blocks (for two different extracts), each one as $3^{\times} 3^{\times} 3$ factorial trial. We used water solutions of methanolic extracts of two mentioned Verbascum species, in three different concentrations (1, 2, and 5\%). Three different larval age groups were used (A1 < 14, A2 14-28, and A3 > 28 days old). Each treatment was repeated three times. The control contained 18 replicates. There were 72 replicates in total. Each assay, placed in a glass Petri dish $(10 \mathrm{~cm}$ in diameter), contained $10 \mathrm{~g}$ of grains treated with $1 \mathrm{~mL}$ of adequate extract solution or $1 \mathrm{~mL}$ of distilled water for the control group and 10 larvae from one of the mentioned age group. Mortality was recorded after 24, 48, 72, and $96 \mathrm{~h}$.

\section{Statistical analysis}

Data were statistically analyzed using the IBM SPSS Statistics 21 software package (2012). The data were subjected to a Repeated Measures ANOVA to evaluate the effect of extracts concentration, time of exposure, larval age, and their interaction on larval mortality. One-way Anova was used for the analysis of the influence of one factor if it showed significance in the previous test. Dunnett T3 test was then used to assess the significance of differences between the treatments. All tests were performed at the level of significance of $95 \%(\mathrm{p}<0.05)$. 
All results were corrected according to Schneider-Orelli’s formula (PÜNTENER, 1981):

$$
\text { Mortality (corrected) } \%=\frac{\text { mortality }(\%) \text { in the treatment }- \text { mortality }(\%) \text { in the control }}{100-\text { mortality }(\%) \text { in the control }} * 100
$$

\section{RESULTS AND DISCUSSION}

The results of the efficacy of $V$. thapsus methanol extract are presented in Table 1 . Generally, this extract caused higher mortality when applied to the younger stage of larvae (A1), compared to the older (A2 and A3), as well as in the highest (5\%) than in lower concentrations ( 1 and 2\%). According to the results of Repeated Measures Anova, there was no significant interaction between time of exposure and concentration of $V$. thapsus extract (Wilk's Lambda $=0.826, \mathrm{~F}=0.486, \mathrm{P}=0.887$, Partial Eta Square $=0.062$ ) but was between the time of exposure and larval age (Wilk's Lambda $=0.478, \mathrm{~F}=3.273, \mathrm{P}=0.01$, Partial Eta Square $=0.309)$. Interaction among all three tested factors was not significant $(\mathrm{P}>0.05)$. However, time of exposure as separate factor had a significantly high effect on the mortality of all larval age groups (Wilk's Lambda $=0.117, \mathrm{~F}=55.41, \mathrm{P}<0.0005$, Partial Eta Square $=$ 0.883). According to the One-way Anova and Dunnett T3 test, concentration had a significant influence $(\mathrm{P}<0.05)$ on larval mortality as presented in Table 1 . According to the One-way Anova and Dunnett T3 test, there was statistically significant influence of concentration $(\mathrm{P}<$ $0.05)$ on mortality after $24 \mathrm{~h}$, when we registered much higher mortality in the A1 age group of larvae when applied 5\% extract $(57.85 \%, \mathrm{P}=0.031)$, then in two younger age groups of larvae (A1 and A2).

Table 1. The mortality (\%) of larval age groups (A1, A2, and A3) of Plodia interpunctella larvae treated with Verbascum thapsus methanol extract applied at different concentrations $(1,2$, and 5\%).

\begin{tabular}{llcccc}
\hline Larval & Concentrations & \multicolumn{4}{c}{ Exposure period } \\
\cline { 3 - 6 } stage & $(\boldsymbol{\%})$ & $24 \mathrm{~h}$ & $48 \mathrm{~h}$ & $72 \mathrm{~h}$ & $96 \mathrm{~h}$ \\
\hline $\mathbf{A 1}$ & 1 & $14.28 \pm 18.55^{\mathrm{a}}$ & $22.22 \pm 11.11^{\mathrm{a}}$ & $20.00 \pm 13.86^{\mathrm{a}}$ & $24.00 \pm 18.33^{\mathrm{a}}$ \\
& 2 & $21.43 \pm 6.19^{\mathrm{a}}$ & $28.52 \pm 16.71^{\mathrm{a}}$ & $24.00 \pm 13.86^{\mathrm{a}}$ & $24.00 \pm 13.86^{\mathrm{a}}$ \\
& 5 & $57.85 \pm 19.2^{\mathrm{b}}$ & $52.96 \pm 14.75^{\mathrm{a}}$ & $48.00 \pm 24.98^{\mathrm{a}}$ & $64.00 \pm 20.78^{\mathrm{a}}$ \\
& $\mathrm{P} ;$ F value & $0.031 ; 6.539$ & $0.085 ; 3.824$ & $0.21 ; 2.048$ & $0.053 ; 5.000$ \\
\hline $\mathbf{A 2}$ & 1 & $17.24 \pm 10.34^{\mathrm{a}}$ & $17.86 \pm 12.37^{\mathrm{a}}$ & $33.33 \pm 11.11^{\mathrm{a}}$ & $52.18 \pm 19.92^{\mathrm{a}}$ \\
& 2 & $18.39 \pm 18.39^{\mathrm{a}}$ & $28.57 \pm 16.37^{\mathrm{a}}$ & $37.04 \pm 23.13^{\mathrm{a}}$ & $52.18 \pm 19.92^{\mathrm{a}}$ \\
& 5 & $24.14 \pm 5.97^{\mathrm{a}}$ & $39.28 \pm 6.19^{\mathrm{a}}$ & $40.74 \pm 6.41^{\mathrm{a}}$ & $56.52 \pm 19.92^{\mathrm{a}}$ \\
& P value & $0.791 ; 0.244$ & $0.187 ; 2.249$ & $0.842 ; 0.176$ & $0.954 ; 0.048$ \\
\hline $\mathbf{A 3}$ & 1 & $0.00 \pm 0.00^{\mathrm{a}}$ & $11.49 \pm 9.95^{\mathrm{a}}$ & $11.49 \pm 9.95^{\mathrm{a}}$ & $11.11 \pm 11.11^{\mathrm{a}}$ \\
& 2 & $10.00 \pm 10.00^{\mathrm{a}}$ & $8.04 \pm 8.68^{\mathrm{a}}$ & $13.79 \pm 5.97^{\mathrm{a}}$ & $40.74 \pm 32.08^{\mathrm{a}}$ \\
& 5 & $6.67 \pm 5.77^{\mathrm{a}}$ & $10.35 \pm 5.97^{\mathrm{a}}$ & $20.69 \pm 15.80^{\mathrm{a}}$ & $22.22 \pm 19.24^{\mathrm{a}}$ \\
& P value & $0.252 ; 1.750$ & $0.879 ; 0.132$ & $0.611 ; 0.536$ & $0.334 ; 1.324$ \\
\hline
\end{tabular}

The results represent mean values $\pm \mathrm{SD}$. Values with the same letter in the column (in superscript) are on the same level of significance, $*-\mathrm{P}<0.05, \mathrm{~ns}-\mathrm{P}>0.05$; A represents the age groups of $P$. interpunctella larvae: A1 < 14, A2 14-28, and A3 > 28 days old.

Verbascum thapsus extract applied in a concentration of 5\% was the most effective in all assays, except against A3 larvae after $96 \mathrm{~h}$, where $2 \%$ concentration was more effective (Table 1). This extract in 5\% concentration showed the biggest success against the A1 group of $P$. interpunctella larvae, with the mortality rate of $57.85 \%$, after only $24 \mathrm{~h}$ of exposure, and 
64.00\% after $96 \mathrm{~h}$ (which was the highest mortality recorded in this research). This extract was less efficient when applied against the older larvae (A2 or A3 group, then against the A1).

The oldest group of larvae (A3) was the most resilient to the extracts of $V$. thapsus. After $24 \mathrm{~h}$ of exposure, the mortality ranged from zero (1\% concentration) to $10 \%$ ( $2 \%$ concentration). As the experiment progressed, the mortality in A3 was higher but still lower in comparison to A1 and A2 groups. The higher percent of mortality in A3 groups (40.74) was registered only $96 \mathrm{~h}$ from the exposure in the treatment where $2 \%$ extract concentration was applied but without statistically significant differences in comparison to replicates with 1 and $5 \%$ concentrations ( 11.11 and $22.22 \%$, respectively, $\mathrm{P}=0.334$ ).

According to the Repeated Measures Anova, there was no significant interaction between time of exposure and concentration of $V$. phlomoides extract (Wilk's Lambda $=$ $0.659, \mathrm{~F}=1.521, \mathrm{P}=0.157$, Partial Eta Square $=0.130$ ). The only time of exposure significantly affected the mortality of larvae (Wilk's Lambda $=0.330, \mathrm{~F}=14.67, \mathrm{P}<0.0005$, Partial Eta Square $=0.670$ ), wherein A1 and A2 age groups the increase in mortality over time was registered (Table 2). One Way Anova was used to test the influence of concentration of extract for each larval age group, after a certain time of exposure, and all results are shown in Table 2 . There was not a statistically significant influence of concentration $(P>0.05$, in all comparisons) on mortality.

Verbascum phlomoides extract was also more effective when applied to the younger than the older $P$. interpunctella larvae (Table 2). In the A1 group larvicidal efficiency of the applied extract varied from $36.01 \%$ (1\% concentration) to the highest $48.00 \%$ (2 and $5 \%$ concentration), $96 \mathrm{~h}$ of the exposure. In the A2 group, the highest mortality (15.94\%) was registered after $96 \mathrm{~h}$ when treated with $5 \%$ extract. In the A3 group, this extract was less effective than in younger groups, after $48 \mathrm{~h}$ of exposure, where $2 \%$ extract caused the highest, but still very low, the mortality of $6.67 \%$ of the tested larvae (the same mortality was registered in the control).

Table 2. The mortality (\%) of larval age groups (A1, A2 and A3) of Plodia interpunctella larvae treated with Verbascum phlomoides methanol extract applied at different concentrations (1,2 and 5\%).

\begin{tabular}{llcccc}
\hline Larval & Concentrations & \multicolumn{4}{c}{ Exposure period } \\
\cline { 2 - 5 } stage & $(\%)$ & $24 \mathrm{~h}$ & $48 \mathrm{~h}$ & $72 \mathrm{~h}$ & $96 \mathrm{~h}$ \\
\hline $\mathbf{A 1}$ & 1 & $3.57 \pm 0.00^{\mathrm{a}}$ & $00.00 \pm 0.00^{\mathrm{b}}$ & $12.82 \pm 16.01^{\mathrm{a}}$ & $36.01 \pm 13.85^{\mathrm{a}}$ \\
& 2 & $10.71 \pm 6.18^{\mathrm{a}}$ & $3.70 \pm 6.41^{\mathrm{ab}}$ & $8.98 \pm 9.68^{\mathrm{a}}$ & $48.00 \pm 30.19^{\mathrm{a}}$ \\
& 5 & $2.38 \pm 2.06^{\mathrm{a}}$ & $11.11 \pm 0.00^{\mathrm{a}}$ & $26.93 \pm 17.62^{\mathrm{a}}$ & $48.00 \pm 18.32^{\mathrm{a}}$ \\
& $\mathrm{P} ;$ F value & $0.069 ; 4.300$ & $0.027 ; 7.00$ & $0.360 ; 1.217$ & $0.751 ; 0.300$ \\
\hline $\mathbf{A 2}$ & 1 & $2.30 \pm 3.98^{\mathrm{a}}$ & $1.19 \pm 2.06^{\mathrm{a}}$ & $11.11 \pm 19.24^{\mathrm{a}}$ & $7.25 \pm 12.55^{\mathrm{a}}$ \\
& 2 & $0.00 \pm 0.00^{\mathrm{a}}$ & $1.19 \pm 2.06^{\mathrm{a}}$ & $0.00 \pm 0.00^{\mathrm{a}}$ & $7.25 \pm 15.25^{\mathrm{a}}$ \\
& 5 & $8.05 \pm 8.68^{\mathrm{a}}$ & $10.71 \pm 6.18^{\mathrm{a}}$ & $14.81 \pm 16.97^{\mathrm{a}}$ & $15.94 \pm 27.61^{\mathrm{a}}$ \\
& $\mathrm{P} ;$ F value & $0.261 ; 1.696$ & $0.051 ; 5.818$ & $0.487 ; 0.813$ & $0.816 ; 0.211$ \\
\hline $\mathbf{A 3}$ & 1 & $3.33 \pm 5.77^{\mathrm{a}}$ & $3.33 \pm 5.77^{\mathrm{a}}$ & $2.3 \pm 3.98^{\mathrm{a}}$ & $0.00 \pm 0.00^{\mathrm{a}}$ \\
& 2 & $3.33 \pm 5.77^{\mathrm{a}}$ & $6.67 \pm 5.77^{\mathrm{a}}$ & $5.75 \pm 9.95^{\mathrm{a}}$ & $3.70 \pm 6.41^{\mathrm{a}}$ \\
& 5 & $0.00 \pm 0.00^{\mathrm{a}}$ & $0.00 \pm 0.00^{\mathrm{a}}$ & $0.00 \pm 0.00^{\mathrm{a}}$ & $0.00 \pm 0.00^{\mathrm{a}}$ \\
& $\mathrm{P} ;$ F value & $0.630 ; 0.500$ & $0.553 ; 0.655$ & $0.553 ; 0.655$ & $0.422 ; 1.000$ \\
\hline
\end{tabular}

The results represent mean values $\pm \mathrm{SD}$. Values with the same letter in the column or number (in superscript) in a row are on the same level of significance, ${ }^{*}-\mathrm{P}<0.05, \mathrm{~ns}-\mathrm{P}>0.05$; A represents the age groups of $P$. interpunctella larvae: A1 < 14, A2 14-28, and A3 > 28 days old. 
According to the literature data, species from the Verbascum genus were tested for insecticidal efficiency only against $S$. oryzae, $T$. castaneum, Rhyzopertha dominica (Fabricius, 1792) (Coleoptera: Bostrichidae) and Callosobruchus maculatus (Fabricius, 1775) (Coleoptera: Chrysomelidae), but not against any lepidopteran storage insect pest (KHOSHNOUD et al., 2008a, 2008b; Khoshnoud and KhAyAmy, 2008; Riaz et al., 2013; Demnati and Allache, 2014). Previously tested Verbascum spp. extracts were usually very efficient as insecticides against target insect species, causing from 64 to 100\% mortality of adults and 100\% supperssion of progeny production. Verbascum thapsus was less efficient against $S$. oryzae and $T$. castaneum, than $V$. cheiranthifolium and V. speciosum (KHOSHNOUD et al., 2008b; KHOSHNOUD and KhaYAMY, 2008; Riaz et al., 2013; DEMNATI and AllaChe, 2014), but in our experiment, satisfactory larvicidal effect against $P$. interpunctella was recorded.

KHOSHNOUD and KHAYAMY (2008) suggested V. cheiranthifolium flowers' extract as a botanical material for the protection of stored wheat from infestations of stored product beetle pests. In their study, ethanolic extract of V. cheiranthifolium caused $100 \%$ mortality of adult $S$. oryzae 21 days after the exposure and complete suppression of the progeny production even at the lowest rate. In the study conducted by RIAZ et al. (2013), V. thapsus methanolic extract was investigated for potential insecticidal efficacy against adult coleopterans $S$. oryzae and $T$. castaneum. However, no significant insecticidal action was observed. The results of our study show that methanol extracts of $V$. thapsus against the youngest $P$. interpunctella larvae have larvicidal efficiency of $64.00 \%, 96 \mathrm{~h}$ after the treatment. In our experiment, the $V$. thapsus extract caused higher mortality of larvae then $V$. phlomoides extract, and the oldest larvae were especially resilient to the $V$. phlomoides extract.

According to previous research, the main phytochemical difference between two extracts tested in our study is in the concentration of verbascoside: $V$. thapsus contains 63.36, while $V$. phlomoides $50.03 \mathrm{mg}$ of verbascoside per g of dry extract (MiHAILOVIĆ et al., 2016). It is already confirmed that crude plant extracts of Calceolaria talcana J. Grau and C. Ehrh (Calceolariaceae), which contain verbascoside as a major phenolic compound, cause high levels of mortality in Drosophila melanogaster (Meigen, 1830) (Diptera: Drosophilidae) and Spodoptera frugiperda (J.E. Smith, 1797) (Lepidoptera: Noctuidae) (MUÑOZ et al., 2013). Previous studies also provided evidence that purified verbascoside can be a very efficient insecticide against Agrilus planipennis (Fairmaire, 1888) (Coleoptera: Buprestidae) larvae (WHITEHILL et al., 2014). It has been discovered that verbascoside may disrupt ecdysteroid metabolism which results in an inhibition of emergence (HESTERLEE and MORTON, 1996).

Verbascum thapsus methanolic extract tested in our study show potential for application as a botanical larvicide since $64 \%$ efficacy was achieved against four days since the exposure against the youngest group of $P$. interpunctella larvae. Verbascum spp. are the undoubtedly important reservoir of verbascoside, rotenone, and other components that could be potentially harmful to the users of the treated crops. Hence, further investigations on the insecticidal efficacy and the safety of possible application of $V$. thapsus extract, dry or crude herbal forms in the protection of stored cereals against $P$. interpunctella for humans and domestic animals are needed. New studies about the insecticidal efficacy of different plant extracts against storage insect pests are in progress.

\section{Acknowledgments}

The research of this paper was financially supported by the Ministry of Education, Science, and Technological Development of the Republic of Serbia (Agreement No. 451-0368/2020-14/200122). 


\section{References:}

[1] BRIGgS, S.A. (1992): Basic guide to pesticides: Their characteristics and hazards. Hemisphere Publishing Corporation. Philadelphia, PA.

[2] Caboni, P., Sherer, T.B., Zhang, N., Taylor, G., Na, H.M., Greenamyre, J.T., CASIDA, J.E. (2004): Rotenone, deguelin, their metabolites and the rat model of Parkinson's disease. Chemical Research in Toxicology 17 (11): 1540-1548. doi: $10.1021 / \mathrm{tx} 049867 \mathrm{r}$

[3] Campos, E.V.R., Proença, P.L.F., Oliveira, J.L., BaKshi, M., Abhilash, P.C., FRACETO, L.F. (2018): Use of botanical insecticides for sustainable agriculture: Future perspective. Ecological Indicators 105: 483-495. doi: 10.1016/j.ecolind.2018.04.038

[4] Dayan, F.E., Cantrell, C.L., Duke, S.O. (2009): Natural products in crop protection. Bioorganic and Medicinal Chemistry 17: 4022-4034. doi: 10.1016/j.bmc.2009.01.046

[5] Demnati, F., Allache, F. (2014): Effect of Verbascum sinuatum (Scrophulariaceae) on oviposition of Callosobruchus maculatus (Bruchidae). Journal of Crop Protection 3 (3): 327-334.

[6] FANG, N., CASIDA, J.E. (1998): Anticancer action of cubé insecticide: Correlation for rotenoid constituents between inhibition of NADH: ubiquinone oxidoreductase and induced ornithine decarboxylase activities. Proceedings of the National Academy of Sciences 95 (7): 3380-3384. doi: 10.1073/pnas.95.7.3380

[7] Foster, S., Duke, J.A. (2003): A field guide to medicinal plants, Eastern and Central N. America. Houghton Mifflin Company, USA.

[8] Georgiev, M.I., Ali, K., Alipieva, K., Verpoorte, R., Choi, Y.H. (2011): Metabolic differentiations and classification of Verbascum species by NMR-based metabolomics. Phytochemistry 72: 2045-2051. doi: 10.1016/j.phytochem.2011.07.005

[9] GrDišA, M., GrŠIĆ, K. (2013): Botanical insecticides in plant protection. Agriculturae Conspectus Scientificus 78 (2): 85-93.

[10] Gross, K.L., WeRner, P.A. (1978): The biology of Canadian weeds: Verbascum thapsus and V. blattaria. Canadian Journal of Plant Science 58. 401-413. doi: 10.4141/cjps78-062

[11] GuPTA, R.C. (2007). Chapter 42 - Rotenone. In: Gupta, R.C. (ed.) Veterinary Toxicology - Basic and Clinical principles. Academic press, pp. 499-501. doi: 10.1016/B978012370467-2/50139-5

[12] GuPTA, R.C. (2019): Biomarkers in Toxicology, second edition. Elsevier Inc., Netherlands: 1246 pp. doi: 10.1016/C2017-0-01788-3

[13] Hartmann, T. (1999): Chemical ecology of pyrrolizidine alkaloids. Planta 207 (4): 483-495. doi: 10.1007/s004250050508

[14] Hesterlee, S., Morton, D. (1996): Insect physiology: The emerging story of ecdysis. Current Biology 6 (6): 648-650. doi: 10.1016/S0960-9822(09)00439-4

[15] IBM Corp. Released 2012. IBM SPSS Statistics for Windows, Version 21.0. Armonk, NY: IBM Corp. 
[16] Isman, M.B. (2006): Botanical insecticides, deterrents, and repellents in modern agriculture and in increasingly regulated world. Annual Review of Entomology 51: 45-66. doi: 10.1146/annurev.ento.51.110104.151146

[17] JaCOBS, B.S., CALvin, D. (1990): Indian meal moth in stored grain. College of Agricultural Sciences, U. S. Department of Agriculture and Pennsylvania Countries Cooperating. 1990.

[18] Jbilou, R., Ennabili, A., Sayah, F. (2006): Insecticidal activity of four medicinal plant extracts against Tribolium castaneum (Herbst) (Coleoptera: Tenebrionidae). African Journal of Biotechnology 5 (10): 936-940.

[19] Khoshnoud, H., Khayamy, M. (2008): Insecticidal effects of ethanolic extract from Verbascum cheiranthifolium Boiss. against two stored-product insect pest species. Journal of Biological Science 8 (1):191-195. doi: 10.3923/jbs.2008.191.195

[20] Khoshnoud, H., Nemati, N., Amirnia, R., Ghiyasi, M., Ghourttapeh, A.H., TAJBAKhsh, M., Talati, F., SAlehZAdeh, H. (2008a): Insecticidal properties of Verbascum cheiranthifolium against $R$. dominica on wheat and barley. Pakistan Journal of Biological Sciences 11 (5): 783-787. doi: 10.3923/pjbs.2008.1380.1384

[21] Khoshnoud, H., Ghiyasi, M., Amirnia, R., Sadig Fard, S., Tahbakhsh, M., SalehZADEH, H., AlaHYARY, P. (2008b): The potential of using insecticidal properties of Medicinal plants against insect pests. Pakistan Journal of Biological Sciences 11: 13801384. doi:10.3923/pjbs.2008.783.787

[22] Mihailović, V., Kreft, S., Benković, E.T., Ivanović, N., Stanković, M. (2016): Chemical profile, antioxidant activity and stability in stimulated gastrointestinal tract model system of three Verbascum species. Industrial Crops and Products 89: 141-151. doi: 10.1016/j.indcrop.2016.04.075

[23] Muñoz, E., Lamilla, C., Marin, J.C., Alarcon, J., Cespedes, C.L. (2013): Antifeedant, insect growth regulatory and insecticidal effects of Calceolaria talcana (Calceolariaceae) on Drosophila melanogaster and Spodoptera frugiperda. Industrial Crops and Products 42: 137-144. doi: 10.1016/j.indcrop.2012.05.014

[24] Navarro, S., Navarro, H. (2018): Insect Pest Management of Oilseed Crops, Tree Nuts, and Dried Friuts. In: Athanassiou, C.G. \& Arthur, F.H. (eds.). Recent Advances in Stored Product Protection, 99-143.

[25] NAyaK, M.K., Daglish, J.G. (2018): Importance of stored food insects. In: Athanassiou, C.G., Arthur, F.H. (eds.). Recent Advances in Stored Product Protection: 1-18.

[26] Phillips, T.W., Berbert, R.C., CuPERus, G.W., Francis, F.J. (eds.) (2000): Post-harvest integrated pest management. Encyclopedia of Food Science and Technology, second edition. Wiley Inc., New York: 2690-2701.

[27] Predojević, D.Z., Vukajlović, F.N., Tanasković, S.T., Gvozdenac, S.M., Pešić, S.B. (2017): Influence of maize kernel state and type on life history of Plodia interpunctella (Lepidoptera: Pyralidae). Journal of Stored Products Research 72: 121-127. doi: 10.1016/j.jspr.2017.04.010

[28] PÜNTENER, W. (1981): Manual for field trials in plant protection, second edition. Agricultural Division, Ciba-Geigy Limited.

[29] RiaZ, M., RAHMAN, N., ZiA-Ul-HaQ, M. (2013): Antihelmintic and insecticidal activities of Verbascum thapsus L. Pakistan Journal of Zoology 45 (6): 1593-1598. 
[30] Saber, M., Hejazi, M.J., Hassan, S.A. (2004): Effects of Azadirachtin/Neemazal on different stages and adult life table parameters of Trichogramma cacoeciae (Hymenoptera: Trichogrammatidae). Journal of Economic Entomology 97: 905-910.

doi: 10.1093/jee/97.3.905

[31] SilhaceK, D.L., Miller, G.L. (1972): Growth and development of the Indian meal moth Plodia interpunctella (Lepidoptera: Phycitidae) under laboratory mass-rearing conditions. Annals of the Entomological Society of America 65: 1084-1087.

[32] Supavarn, P., KnapP, F.W., Sigafus, R. (1974): Biologically active plant extracts for control of mosquito larvae. Mosquito News 34: 398-402.

[33] Vukajlović, F., Predojević, D., Milošević, S., Radulović, D., Pešić, S. (2017): Survival rate of Plodia interpunctella (Lepidoptera: Pyralidae) on different states of wheat and rye kernels previously infested by beetle pests. Kragujevac Journal of Science 39: 201-208.

[34] Vukajlović, F.N., Pešić, S.B., Tanasković, S.T., Predojević, D.Z., Gvozdenac, S.M., PrVulović, D.M., Bursić, V.P. (2019): Efficacy of water extracts from Echium spp. (Boraginaceae) as potential post-harvest grain protectants against Plodia interpuncttella (Lepidoptera: Pyralidae) larvae. Romanian Biotechnological Letters 24 (5): 761-769. doi: $10.25083 / \mathrm{rbl} / 24.5 / 761.769$

[35] Whitehill, J.G.A., Rigsby, C., Cipollini, D., Herms, D.A., Bonello, P. (2014): Decreased emergence of emerald ash borer from ash treated with methyl jasmonate is associated with induction of general defense traits and the toxic phenolic compound verbascoside. Oecologia 176 (4): 1047-1059. doi: 10.1007/s00442-014-3082-8

[36] YANG, R.Z., TANG, C.S. (1988): Plants used for pest control in China: A literature review. Economic Botany 42 (3): 376-406. 
